\title{
GENETIC DIFFERENTIATION OF POPULATIONS OF HONEY BEE (Apis mellifera L.) AND DISTRIBUTION OF RNA-CONTAINING VIRUSES AT THE BACKGROUND OF EPIZOOTIA OF Varroa destructor ON THE TERRITORY OF UDMURTIA
}

\author{
Alexander E. Kalashnikov*, Ivan V. Maslennikov**, Ludmila M. Kolbina**, Irina G. Udina* \\ *N.I. Vavilov Institute of General Genetics RAS \\ **Udmurt Research Institute of Agriculture
}

\begin{abstract}
The bees of dark forest species (Apis mellifera mellifera L.) are winter-hardy. These bees are able to effectively use a short honey harvest. Introgression of southern bee species in the Russia affects ro the economic quality of local northern species of bees. Introgression of species reduces their immunity, thereby It was enhancing susceptibility bees to infection with ectoparasites, as well as distribution of various viral diseases. Varroa destructor mite infestations on bees may predispose to infection by viruses. We have presented data about population differentiation of bees of dark forest species in Udmurtia, which were obtained based on the study using PCR method, morphometric parameters (cubital index of wing) and estimation of variability in intergenic locus of the CO-I-COII of mtDNA. Based on the analysis of the mtDNA the hybridization degree in samples of bees from Udmurtia 1UD_S and 5UD_S (maternal line) was 15.4 and $60.0 \%$, respectively. Sample 2D_S4UD_S meet the standards of dark forest bee species. For all analyzed samples (1UD_S-5UD_S) obtained average rating of cubital index $>0.55$. These data confirmed the high probability of belonging of bees of sample data to the dark forest bee species. However, the variability analysis (according to the length of the intergenic locus CO-I-CO-II) with Southern species hybridization was observed only in samples 2UD_S-4UD_S, whereas in the other samples 1UD_S 5UD_S hybridization has occurred. This indicates a greater degree of reliability of molecular techniques in the evaluation of the degree of hybridization when samples of bees were studied. It's interesting that in one of the samples 2UD_S we founded a heteroplasmy PQ/P3* Q. In bees exposed to Varroa destructor defeat was detected deformed wing virus (DWV) (23,3\% of families), chronic bee paralysis virus (CBPV) and sacbrood bee virus (SBV) $(13,3 \%)$.
\end{abstract}

\section{Keywords}

honey bee, Apis mellifera L., mitochondrial DNA, cubital index, deformed wing virus, sacbrood virus, chronic paralysis virus, Varroa destructor

\section{Introduction}

The dark forest bee Apis mellifera mellifera $\mathrm{L}$. and related subspecies of Central Russian bee breed was widespread in Russia (1), including Udmurtia (2) and Bashkortostan (3). These bees have winter hardiness, resistance to several diseases, the ability efficiently uses a short honey harvest. The proboscis of these bees is short (6.0-6.4 mm). They have a dark color of the body. For these bees is a characteristic light dry seal of honey. However, these bees are aggressive and have a tendency to increase swarming. The cubital index value of the breed standard of these bees is in the range 0.60-0.65 (4).

Under the influence of anthropogenic factor in Russia, like in Western Europe and North America, there was observes a hybridization of $A$. $m$. mellifera subspecies with subspecies, which are spread in the more southern latitudes. Integration of the southern subspecies effect on economic quality of the local northern species, as well as have a negative impact on their adaptability to environmental conditions. It also reduces immunity, thereby enhancing susceptibility of bees to infection of ectoparasites and distribution of various diseases, including viral (5).

Infection bee mite Varroa destructor bees predispose to infection by viruses (5-7). Mite serves as a reservoir for virus bee mite infestation therefore weaken their immunity and promotes viral infection (8). Six of the studied viruses of the honey bee cause serious consequences if infected, up 
to the death of bee colonies. Among such viruses are deformed wing virus (DWV), acute bee paralysis virus (ABPV), chronic bee paralysis virus (CBPV), Kashmir bee virus (KBV), sacbrood bee virus (SBV) and Black queen cells virus (BQCV) (6).

Our objective was to investigate the differentiation of bee populations in Udmurtia using morphometric method (determination of cubital index) and analysis of variability of the CO-I-CO-II intergenic locus of mitochondrial DNA, as well as identifying the spread of RNA viruses in bees.

\section{Material and Methods}

We used the bees from the territory of Udmurtia. For the investigation of cubital index and analysis of the mtDNA sampled bees in the districts of Krasny Yar (1UD_S) (N = 11), B. Ucha (2UD_S) (N = 24), Motorke (3UD_S) $(\mathrm{N}=23)$, Izhevsk $9 \mathrm{~km}\left(4 \mathrm{UD} \_\mathrm{S}\right)(\mathrm{N}=8)$ and Votkinsky District (5UDDS) $(\mathrm{N}=7)$. The samples for the study of RNA viruses harvested from 30 families on an apiary located on the 9 th $\mathrm{km}$ of Yakshur-Bodyinsky tract $(\mathrm{N}=90)$. All samples were combined for 3 samples from each bee family in a sample pool, which later was analyzed by RT-PCR. This apiary in the woods during the winter were lost 2 colonies. In the apiary established high mite Varroa destructor infestation of more than $40 \%$ at acceptable rate of $2 \%$.

The study of morphometric characters carried out as recommended by the protocol of the Research Institute of Agricultural Sciences of bee (4). The cubital index value specified as a fraction of one. DNA from the thoracal department isolated by a set of "Diatom DNA prep 400" (Izogen, Russia). PCR of mtDNA was performed using a set of "Screen Mix" (Evrogen Co., Russia). Extraction of RNA was performed using a kit "Trizol" (Izogen, Russia). Because genetic material of the virus is presented by RNA, in the first step RT-PCR cDNA generated using the enzyme reverse transcriptase. The obtained cDNA serves as a template in the subsequent PCR stages. Determination of the presence of the viral infection was carried out by RT-PCR using the kit "GenPack RT-PCR Core" and PCR of mtDNA by "Screen Mix" (Izogen, Russia) with primers (1, 2, 3).

In the reaction of RT-PCR used primers $(6,8)$. Determining the type of species (north or south type) was carried out by PCR analysis of the length of the intergenic locus COI-COII $(1,2,3)$. This area contains a length of $\mathrm{P}$ element $54 \mathrm{bp}$ and then variability of the number of element $\mathrm{Q}$, which differ bees of southern and northern populations. The investigated region of the mitochondrial genome is located between the 3 'region of the gene and the $5^{\prime}$ region of COI gene COII. Its total length of 50 bp It is known that in the studied region bees of southern species contains one element Q (length $196 \mathrm{bp}$ ), and the bees northern populations of two or more elements Q.

The mathematical and statistical analysis was performed Using the software "Excel" (Microsoft, USA). Image processing was performed in the program Corel X13 (Corel, USA).

\section{Results}

The average value of the cubital index of the population calculated as the average value for all population. The value of cubital index may be an indication of hybridizing species at formation the studied population or it compliance with this population (sample) pedigree standard for morphometric indices in general.

From studies founded that the average values of the cubital index of Udmurt populations 1UD_S, 2UD_S, 3UD_S, 4UD_S and 5UD_S less than the standard of the breed for 17, 7, 7, 8 and 10\%, respectively (Table. 1). The intergenic region locus COI-COII site in the samples analyzed by PCR (Table. 1).

Table 1 - Morphometric Parameters and the Frequency of Mitotypes in Populations

\begin{tabular}{|c|c|c|c|c|c|c|c|c|c|c|c|}
\hline & \multirow[t]{2}{*}{ Sample } & \multirow[t]{2}{*}{$N$} & \multirow{2}{*}{$\begin{array}{c}\text { Cubital } \\
\text { Index }\end{array}$} & \multirow{2}{*}{$\begin{array}{c}\text { Confidence } \\
\text { Interval }(P= \\
0,05)\end{array}$} & \multirow[t]{2}{*}{$C V$} & \multirow[t]{2}{*}{ Min } & \multirow[t]{2}{*}{$\operatorname{Max}$} & \multicolumn{3}{|c|}{ Variants of Mitotypes } & \multirow{2}{*}{$\begin{array}{c}\text { The Degree } \\
\text { of } \\
\text { Interbreedin } \\
g, \%\end{array}$} \\
\hline & & & & & & & & $\begin{array}{l}350 \\
P Q\end{array}$ & $\begin{array}{c}546 \\
\text { PQQ }\end{array}$ & $\begin{array}{c}546 / 796 \\
\text { PQQ/ } \\
\text { P3xQ }\end{array}$ & \\
\hline 1 & 1UD_S & 11 & 0,50 & $\pm 0,04$ & 0,13 & 0,41 & 0,60 & 0,15 & 0,85 & & 15,4 \\
\hline 2 & 2UD_S & 24 & 0,56 & $\pm 0,04$ & 0,18 & 0,32 & 0,75 & & 0,96 & 0,04 & 0 \\
\hline 3 & 3UD_S & 23 & 0,56 & $\pm 0,03$ & 0,13 & 0,43 & 0,72 & & 1,00 & & 0 \\
\hline
\end{tabular}




\begin{tabular}{l|lllllllllc}
4 & 4UD_S & 8 & 0,55 & $\pm 0,03$ & 0,09 & 0,50 & 0,63 & & 1,00 & 0 \\
5 & 5UD_S & 7 & 0,54 & $\pm 0,05$ & 0,13 & 0,45 & 0,62 & 0,60 & 0,40 & 60,0 \\
\hline
\end{tabular}

By analyzing of mtDNA the degree of hybridization of bees through the maternal line in samples 1UD_S 5UD_S was 15.38-60.00\%, respectively. Samples 2UD_S - 4UD_S meet the standards of dark forest bee breed.

For the bee samples 1UD_S - 5UD_S average rating of cubital index $>0.55$, which indicates a high probability of their belonging to the dark forest bee. However, according to the analysis of the variability of the length of the intergenic locus COI-COII hybridization was not observed with the southern species samples only 2UD_S - 4UD_S, and for 1UD_S 5UD_S UDS detected hybridization with southern species. It's interesting that in one sample, sample 2UD_S detected heteroplasmy PQ / p3xQ.

For the bees from an urbanized area of Bashkortostan it was previously also observed a decrease in the mean cubital index of $5.25 \%$ and the presence of mitotype PQ, typical of southern species. In some populations of bees the level of hybridization with the southern rock (with the Carpathian breed) reached 50\%. In areas of Udmurtia with low population density (sample 2UD_S 3UD_S), as well as for forest areas of Bashkortostan (Burzyatinskaya population, State Reserve Shulgan-Tash), marked a very low degree of interbreeding the dark forest bee bees (not more than 0.01), the frequency mitotype PQQ was at least 0.99) (3).

Currently the cause of the hybridization of different species of bees due to the human factor, because beekeepers often preferred to breed in areas of primary distribution of the dark forest bee species more peaceful Carpathian bees. The data on co-infection of bee colonies by several RNA viruses suggests the role of these infections in the syndrome of mass destruction - the collapse of bee colonies $(6,7)$.

An important cause of death of bees is Varroa mite- heavy leaking that can't be still complete recovered, a parasitic disease of bee colonies with the simultaneous defeat of worker bees, drones, queen's brood $(8,9)$. The source of infection is an infected tick colonies. Mite spreads through wandering bees, as well as through bee-thieves, drones, with swarms, with migrations apiaries, the purchase and sale bees and queens and others. Main place of concentration of mite in the active period is capped brood and bees inside the hive. Drone brood is affected in 7-15 times more than the worker brood. Propagation data of Varroatosis in Udmurtia are shown in Figure 1

In Russia causes of viral diseases of bees were known, such as virus strain wing [5] and other viruses [6]. To study the propagation of RNA viruses in Udmurtia sampled the biological material on apiaries where was observed the death of bee colonies and their defeat Varroa. It was found that DWV was the most widespread (7 families, 23.3\%). The virus is most common in families of bees infected with $V$. destructor [3, 4]. CBPV and SBV were observed in 4 families (freq. 13.3\%). 


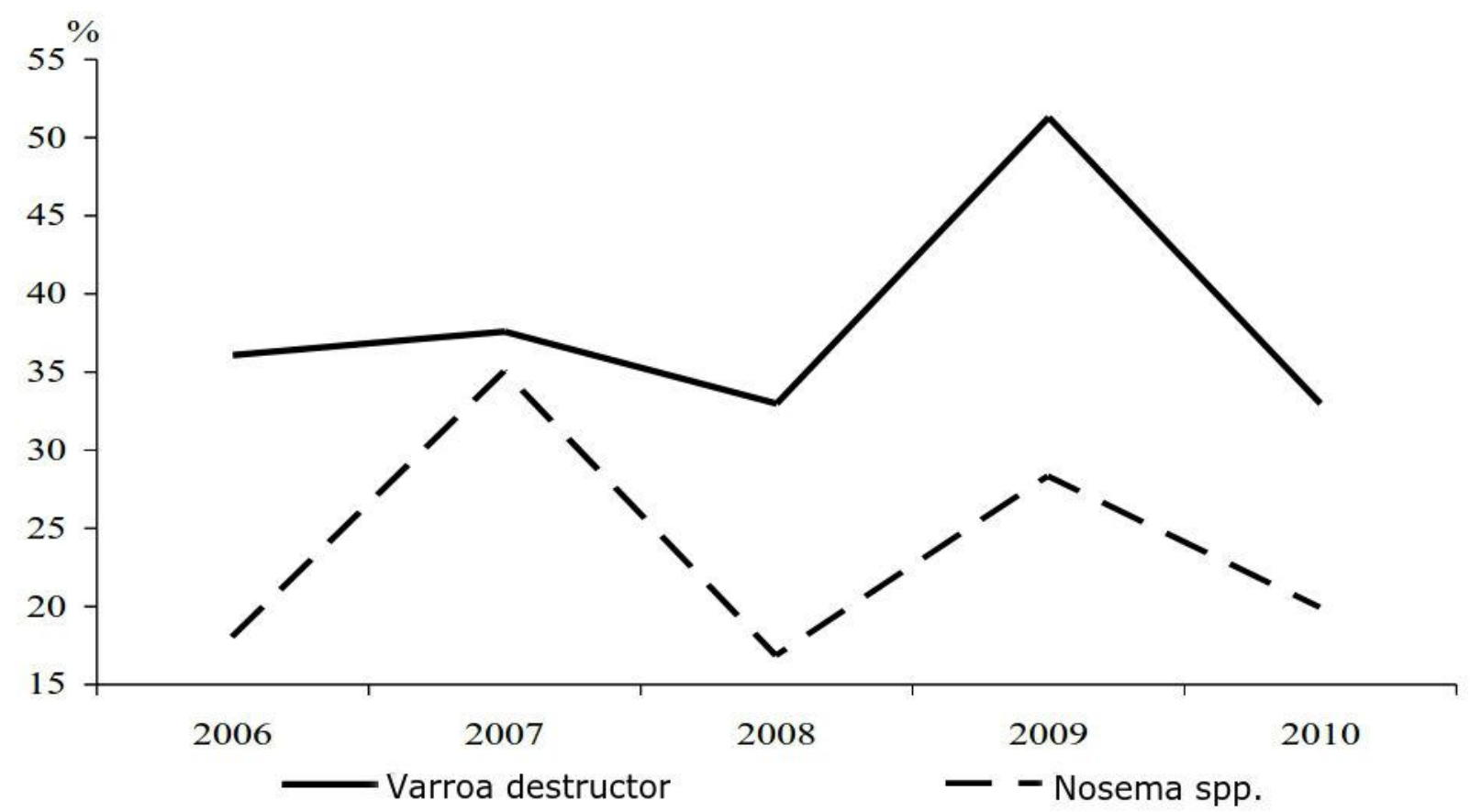

Figure 1. The most common diseases, according to the Udmurt Agricultural Research Institute received in the course of research: "Monitoring of the epidemiological situation and evaluation of the causes of the collapse of bee colonies in the Udmurt Republic").

The number of viruses wasn't less than 2 simultaneous detection and it was observed in 4 cases $(13.3 \%)$, not less than 3 in 1 case (3\%). It was marked by simultaneous infection with viruses DWV SBV, and DWV ABPV. Moreover, it should be noted that SBV is most efficiently detected by PCR compared to its detection in clinical manifestations of the disease.

In the works of researchers Berenyi O. [8] and Miranda J. et al [9] also identified both viruses DWV and SBV, as well as DWV and ABPV. Authors have been noted and other mixed viral infections. We can assume that the mixed viral infections can cause death of bee colonies and, in certain circumstances, it was resulted in the collapse of bee colonies [9].

Thus, we have been behavioral analysis purebred simultaneously cubital index and variability of the intergenic locus COI-COII of mtDNA revealed the population of bees, which are dark forest bee species. It was revealed that methods of analysis of cubital index and mtDNA complement each other, but the molecular method gives more reliable results. It was founded that the bees are present in Udmurtia RNA viruses bees, which can be fatal. In most samples, there is a combined infection, which increases the risk of death of the bee family.

\section{Acknowledgements}

This work was performed as part of grants for legal entities to support scientific research in the framework of implementation of 1.1-1.5 (Federal Program "Scientific and scientific-educational personnel of innovative Russia) 2009-2013 (agreement №8088 on 23 July 2012 between the Ministry of Education and Science of the Russian Federation, Russia Academy of Sciences and State Organization N.I. Vavilov Scientific Institute of General Genetics of Russia Academy of Sciences). The work is also supported by a grant from the World Wide Fund for bees (s.V. Foundation) on "Monitoring of the Epidemiological Situation and Estimation of the Reasons of the Collapse of Bee Colonies in the Udmurt Republic " (an agreement to support scientific and practical projects №01-DF/F).

\section{References}

1. Krivtsov NI, Gorjacheva II, Udina IG, Borodachev AV, Monakhova MA. Identification of species and populations of honeybee using the PCR method. 2010. Agricultural Biology 
(Selkohozajstvennaja biologia). 6. P. 26-29.

2. Nepeivoda SN, Kolbina LM, Vorobieva SL, Sannikova NV, Maslennikov IV, Iliasov RA, Nikolenko AG. Analysis of the population differentiation Apis mellifera in Udmurtia. 2011. Beekeeping J. 10. P. 12-13.

3. Nikonorov YM, Bieńkowska GV, Poskryakov AV, Nikolenko AG, Vahitov VA. Using PCR method for the control of pure breed of bee colonies Apis mellifera mellifera $\mathrm{L}$. in the conditions of the Southern Urals. 1998. Russian J Genetics. (11). P.1574-1577.

4. Borodachev AV, Burmistrov AN, Kasyanov AI, Krivtsova LS, Kryvtsov NI, Lebedev VI, Martynov AG, Solovyov LF, Kharitonov NN. 2002. Methods of scientific research in beekeeping. Rybnoe. P.1-154.

5. Udina IG, Kunizheva SS, Grishechkin AE, Kalashnikov AE, Uchaeva VS, Krivtsov NI, Zlobin VI. Detection of the virus strain wing in honeybee Apis mellifera L. on apiaries in the Moscow region by RT-PCR. 2010. J Vopr Virusologii. 5. P.37-40.

6. Kalashnikov AE, Udina IG. Distribution of RNA viruses in the honeybee Apis mellifera L. in Russia. 2012. Vet Pharma. Pharm animals. 2012. 1. P.72-76.

7. Kolbina LM, Sannikova NA, Vorobyova SL, Nepeivoda SN, Pankov EV, Maslennikov IV, Kalashnikov AE, Udina IG. About a viral infection of bees in the Republic of Udmurtia. 2012. Beekeeping J. 8. P. 35.

8. Berenyi O., Bakonyi N., Derakhshifar I., Koglberger H., Nowotny N. Occurrence of six honey bee viruses in diseased Austrian apiaries. 2006. Appl Envir Microbiol. 72(4). P. 2414-2420.

9. Miranda JR, Cordoni G., Budge G. The acute bee paralysis virus- Kashmir bee virus- Israeli acute paralysis virus complex. 2010. J Invertebr Pathol. 103(1). P.30-47. 